\title{
The Determination of Deteriorations on The Mısırlığlu Bridge (Konya, Turkey) by Non-Destructive Techniques (NDT)
}

\author{
Mehmet Bahadır Tosunlar \\ Mehmet Ergün Hatır \\ İsmail İnce \\ Ali Bozdağ ${ }^{* \star}$ \\ Mustafa Korkanç
}

\section{Abstract}

Transportation has been one of the basic requirements of humanity since the earliest periods of civilization. One of the architectural structures designed to meet this requirement is historic stone bridges. One of the most important stages in these conservation works is the assessment of materials that constitute the structures. Non-destructive testing techniques (NDT) are widely used to obtain qualitative data and also make comparisons. In this study, it was aimed to determine deteriorations on the Misırlığlu Bridge located in Sille settlement of Konya by NDT technique and to form the map from obtained values to perform conservation works. As a result of the analyses performed, considerable deteriorations in the building stones used in the abutments and arches of the structure were determined. Besides, it is detected that uniaxial compressive strength (UCS) value of the fresh samples is high (UCS: $61 \mathrm{MPa}$ ) while UCS values of the building stones used at the bridge decrease in the range of low and high (8-51 MPa) due to the atmospheric effects.
Keywords: Deterioration, Konya, Mısırlıoğlu Bridge, non-destructive tests (NDT), Sille

* Res. Assist., Department of Architecture, Faculty of Architecture and Design, Konya Technical University, Konya, Turkey.

E-mail: mbtosunlar@selcuk.edu.tr

Orcid ID: http://orcid.org/0000-0001-9061-3422

** Res. Assist., Department of Architecture, Faculty of Architecture and Design, Konya Technical University, Konya, Turkey.

E-mail: ergunhatir@gmail.com

Orcid ID: http://orcid.org/0000-0003-0460-0583

*** Res. Assist. Dr., Department of Geological Engineering, Faculty of Engineering and Natural Sciences, Konya Technical University, Konya, Turkey.

E-mail: iince@selcuk.edu.tr

Orcid ID: http://orcid.org/0000-0002-6692-7584

**** Res. Assist. Dr., Department of Geological Engineering, Faculty of Engineering and Natural Sciences, Konya Technical University, Konya, Turkey.

E-mail: abozdag@selcuk.edu.tr

Orcid ID: http://orcid.org/0000-0003-2590-8798

Assoc. Prof., Department of Geological Engineering, Faculty of Engineering, Niğde Ömer Halisdemir University, Niğde, Turkey.

E-mail:mkorkanc@ohu.edu.tr

Orcid ID: http://orcid.org/0000-0001-7382-8077 
Mehmet Bahadır Tosunlar \& Mehmet Ergün Hatır \& İsmail İnce \& Ali Bozdağ \& Mustafa Korkanç

\section{INTRODUCTION}

Konya is an important city that dates back to the Neolithic periods and later, hosted the Hittite, Phrygian, Greek, Roman, Byzantine, Anatolian Seljuk, and Ottoman civilizations. One of the oldest settlements in the city is Sille settlement. Sille is located approximately $11 \mathrm{~km}$ northwest of Konya. Sille is a settlement where many cultures lived together in tolerance and harmony until the beginning of the 20th century. In Sille, which is famous for its stonemasonry, there are many architectural works that reflect the cultural richness of civilizations from the past to the present (Beycan, 2017). These architectural works are mostly built with Sille stone of volcanic origin (dacite, andesite and rhyolite) quarried from the region. Some of the monuments that constitute the cultural texture of the region are the Aya Elena Church, Çay Mosque, Karataş Mosque, Sille Tepe Chapel, Ak Hamam (Bathhouse), and Mısırlığlu Bridge (Figure 1).

Figure 1. Some samples of the monuments in Sille settlement; a) Aya Eleni Church, b) Çay Mosque, c) Karataș Mosque, d) Sille Hill Chapel, e) Ak Hamam (Bathhouse), f) Mısırlığlu Bridge.



Sille stone, which constitutes the architectural texture of the region, is subjected to deterioration processes as a result of atmospheric effects (Fener and Ince, 2015). It is very important for the restoration practices to be carried out to determine the extent to which the deteriorations of the structures forming the cultural texture in the region have been developed. The interdisciplinary studies (architectural, civil and geological engineering, chemistry, biology, etc.) aimed at determining 
deterioration in situ and in the laboratory have recently become prominent (Korkanç, 2013). In-situ analyses include systematic field observations, documentation, measurement, and drawing techniques. Laboratory studies are based on determining the index, strength, mineralogical and petrographic properties of building stones. However, the relations between the laboratory values and the deterioration grades of stone materials in the structure cannot be located on the structure one to one. NDT applications, which have become widespread in recent years, allow obtaining the deterioration data only by contact, without damaging historical monuments. Furthermore, deterioration identifications can be made by comparing the deterioration data obtained by NDT with the geomechanical properties of the building material obtained in the laboratory (Delgado Rodrigues, 2015).

Although there are studies in the literature on the engineering properties of Sille stone (Ozdemir, 2002) and the deterioration processes of the rock by rapid deterioration tests (freeze-thaw and salt crystallization) (Fener and Ince, 2015; Zedef, Kocak, Doyen, Ozsen, and Kekec, 2007), there are no studies on the deterioration processes of this stone used in historical monuments. In this study, deteriorations on the Sille Mısırlığlu Bridge, which is one of the monuments where load and humidityrelated damages are observed intensively, were tried to be determined with NDT. Therefore, in-situ tests (humidity measurement and Schmidt hammer rebound tests) were applied to the structure. By comparing the results of the Schmidt hammer test on the rock and historical structure, deterioration mapping was performed and risky areas in the structure were determined.

\section{MATERIALS AND METHODS}

This study consists of the two stages; the first is determination of the index-mechanical properties of Sille stone in the laboratory, and the second is non-destructive testing (NDT) performed on the Mısırlığlu Bridge. For laboratory studies, homogeneous block samples, which were similar to the stones used in the construction of the historical monument, were collected from ancient stone quarries which are very close to monument. In order to determine the index-mechanical properties of the rocks from these samples, suitable core samples for the relevant standards were prepared. To determine the deterioration, relative humidity (RH) and Schmidt hammer rebound (SHR) tests were carried out in the area. Additionally, the geochemical characteristics of rocks were made in the ACME Laboratory, Canada.

\section{DESCRIPTION OF THE MISIRLIOĞLU BRIDGE}


Mehmet Bahadır Tosunlar \& Mehmet Ergün Hatır \& İsmail İnce \& Ali Bozdağ \& Mustafa Korkanç

The Mısırlıoglu Bridge is located on the Çaybağ Creek in Sille settlement located in the northwest part of Konya city centre (Figure 1.f). The bridge is of a one-eyed arch type and was built by the masonry technique using 104 pitch-faced stones and block stones on the northwest side and 111 pitch-faced stones and block stones on the southeast side. The bridge is $7.18 \mathrm{~m}$ in length, 2.72 $\mathrm{m}$ in width, and $4.31 \mathrm{~m}$ in height. The stone railings forming the upper structure of the bridge are connected to each other by iron cramps to limit the pedestrian line. Though the bridge has no inscription on it, but the construction is considered to date back to the $19^{\text {th }}$ century (Karpuz, 2009).

\section{INDEX-STRENGTH PROPERTIES}

Values of porosity and water absorption by weight were determined using saturation and calliper techniques. NX size core samples were used in these tests (ISRM, 2007). Trimmed core samples were used to determine dry densities and P-wave velocity according to ISRM (2007) standards. The uniaxial compressive strength tests were conducted on core samples having a diameter of $54 \mathrm{~mm}$ and a length-to-diameter ratio of 2.02.5 (ASTM, 1986). Böhme abrasion tests were conducted in accordance with EN-14157 (2004) using an abrasion testing machine.

\section{PETROGRAPHIC AND GEOCHEMICAL PROPERTIES}

Sille stone has a light-dark pink colour, and the rocks have aphanitic porphyritic textures in macro samples (Figure 2a, c). In the polarized microscopy of the fresh samples of Sille stone taken from the quarry and the decomposed samples taken from the bridge, $29 \%$ plagioclase, $26 \%$ volcanic glass, $19 \%$ biotite, $17 \%$ plagioclase microlite, $8 \%$ quartzite, and $1 \%$ opaque mineral were observed (Figure 2b, d). The geochemical composition of both fresh and decomposed samples is presented in Table 1. According to the TAS diagram proposed by Le Bas, Le Maitre, Streckeisen, and Zanettin (1986), the samples are named as dacite (Figure 3). Thin section examination and geochemical data of the samples exhibit similar characteristics. According to the obtained data, this bridge is made of Sille stone. 
The Determination of Deteriorations on The Misırlıoglu Bridge (Konya, Turkey) by Non-Destructive Techniques (NDT)
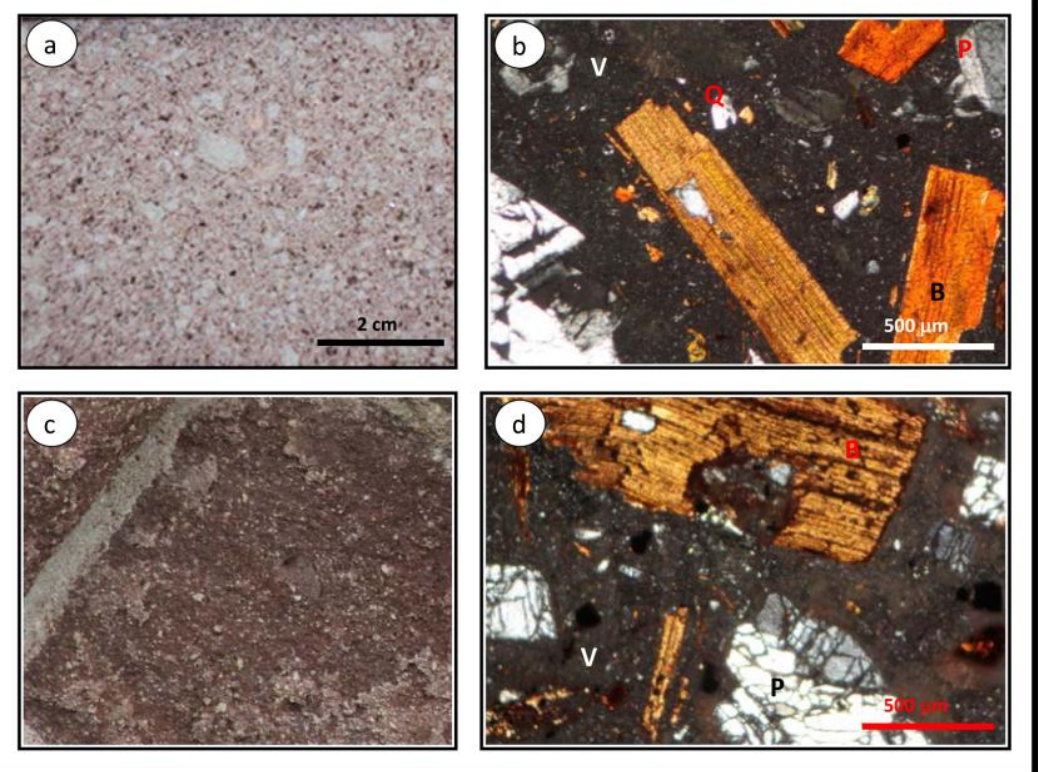

Table 1. Chemical composition of the rock samples.

\begin{tabular}{lccccccccccccc}
\hline \multirow{2}{*}{ Sample } & \multicolumn{10}{c}{ Major element oxide (\%) } \\
\cline { 2 - 12 } & $\mathrm{SiO}_{2}$ & $\mathrm{Al}_{2} \mathrm{O}_{3}$ & $\mathrm{Fe}_{2} \mathrm{O}_{3}$ & $\mathrm{MgO}$ & $\mathrm{CaO}$ & $\mathrm{Na}_{2} \mathrm{O}$ & $\mathrm{K}_{2} \mathrm{O}$ & $\mathrm{TiO}_{2}$ & $\mathrm{P}_{2} \mathrm{O}_{5}$ & $\mathrm{MnO}^{-}$ & $\mathrm{Cr}_{2} \mathrm{O}_{3}$ & LOI \\
\hline Fresh sample & 68.68 & 14.24 & 3.35 & 2.02 & 3.67 & 3.16 & 3.52 & 0,42 & 0,10 & 0,08 & 0,002 & 0,53 \\
Deterioration sample & 66,81 & 14,77 & 3,52 & 2,18 & 4,03 & 3,50 & 3,60 & 0,44 & 0,12 & 0,09 & 0,002 & 1,38 \\
& & & & & & & & & & & &
\end{tabular}

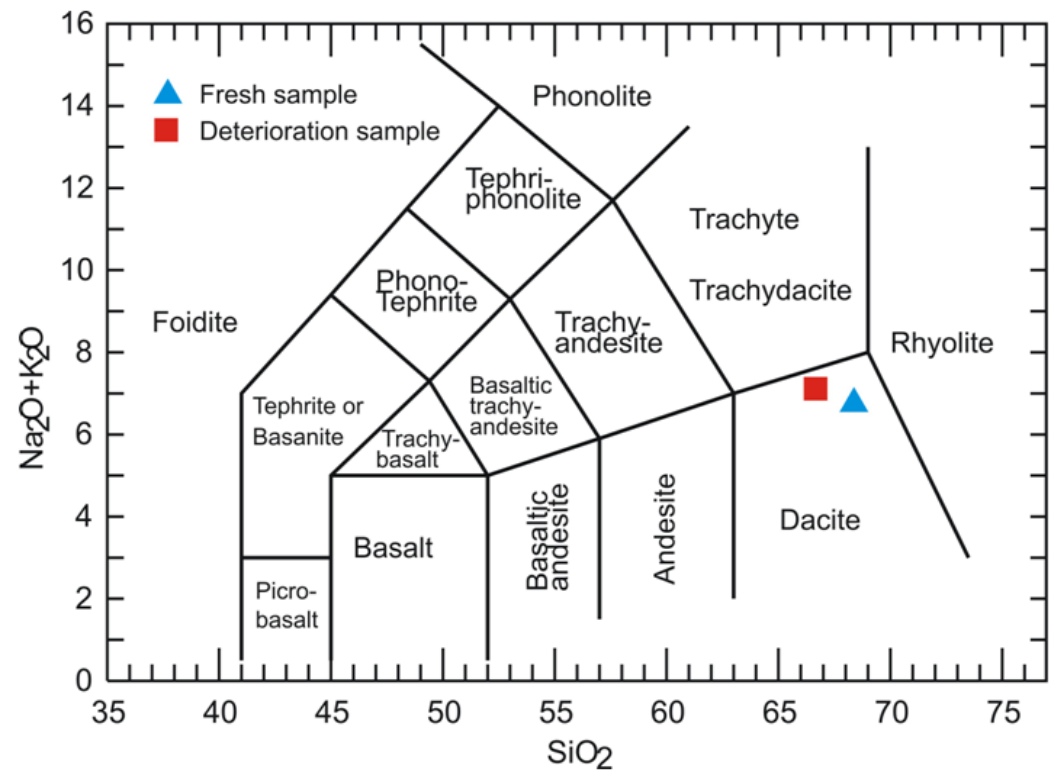

\section{IN-SITU TEST}

In the field and laboratory studies, rock's hardness was determined using Schmidt hammer type-L. The Schmidt hammer rebound test was conducted in accordance with the methods proposed by the standard ASTM (2014). Relative humidity values
Figure 2. Macroscopic image of samples a) fresh, c) deterioration, microscopic image of samples b) fresh, d) deterioration (crossed polars)(P:plagioclase,B:biotite,V:vol canic glass, Q: quartzite).

Figure 3. TAS (Total Alkali vs. Silica) diagram of (Le Bas, Le Maitre, Streckeisen, and Zanettin, 1986). 
Mehmet Bahadır Tosunlar \& Mehmet Ergün Hatır \& İsmail İnce \& Ali Bozdağ \& Mustafa Korkanç

of the building stones were determined by using Trotec T660 equipment.

\section{MAPPING}

Serial photos were taken to prepare the deterioration maps of the Misırlığlu Bridge, with Cannon EOS 600D camera and then orthophotos were attained from these photos by using Agisoft PhotoScan Pro (64bit) program (Figure 4a). Subsequently, the original design of the monument was prepared (Figure $4 b-c$ ). Finally, data obtained from non-destructive tests (NDT) were processed on this drawing (Figure 4d-e).

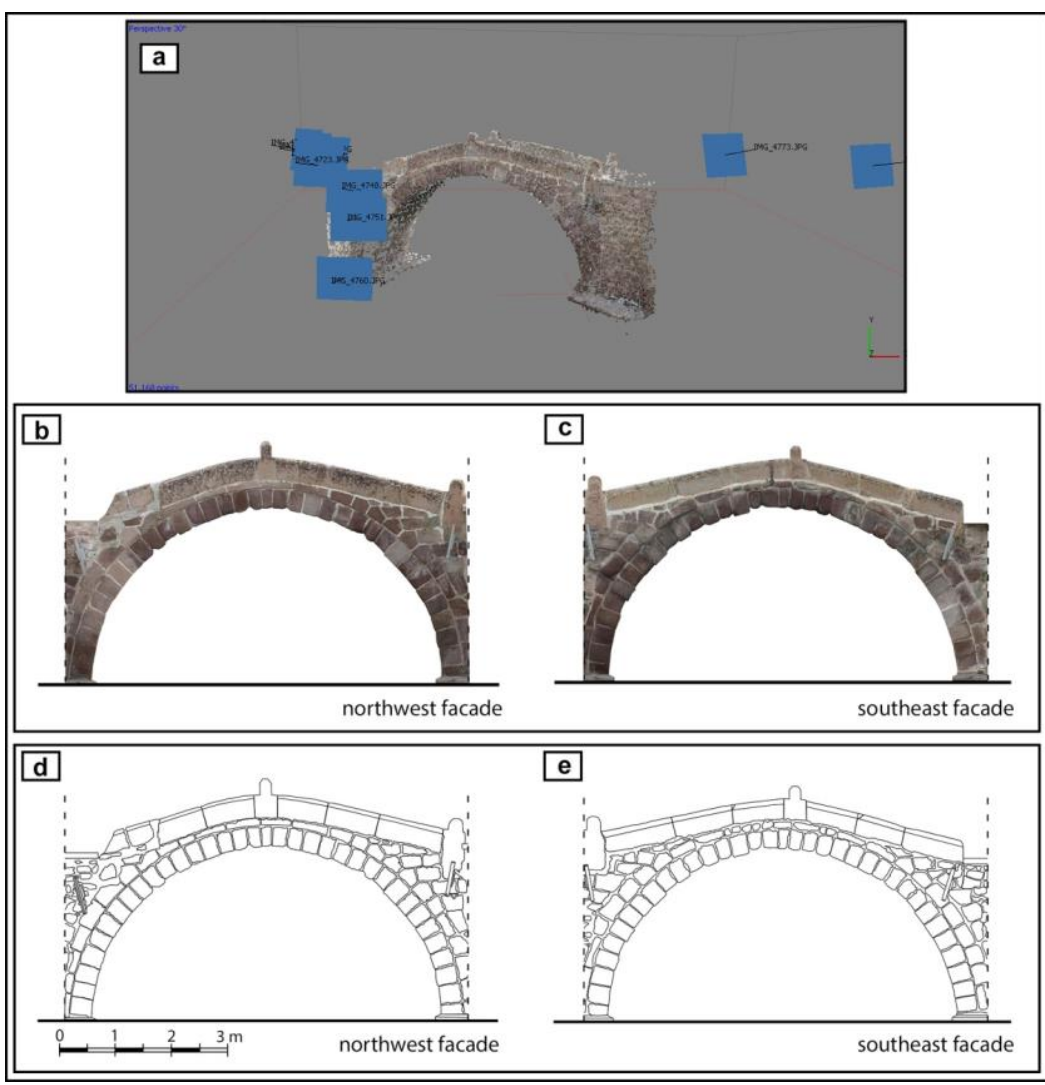

Figure 4. Image modelling and drawing stages a) the stage of processing structure photographs with Agisoft PhotoScan Pro, b-c) orthophoto image, d-e) survey drawings.

\section{RESULTS AND DISCUSSION}

\section{INDEX-STRENGTH PROPERTIES}

Some geomechanical properties of Sille stone are given in Table 2. Mean values of dry density ( $\rho d)$, porosity (n), water absorption by weight (aw), P-wave velocity (Vp) and Böhme abrasion loss value (BA) were determined as $2.32 \mathrm{~g} / \mathrm{cm} 3,5.60 \%, 2.43 \%, 3.72 \mathrm{~km} / \mathrm{s}$ and $16.05 \mathrm{~cm} 3 / 50 \mathrm{~cm} 2$, respectively. 
The Determination of Deteriorations on The Misırlığlu Bridge (Konya, Turkey) by Non-Destructive Techniques (NDT)

Table 2. Some geomechanical parameters of Sille stone (mean value).

\begin{tabular}{lccccccc}
\hline & \multicolumn{8}{c}{ Properties } \\
\cline { 2 - 8 } Sample & $\begin{array}{c}\rho_{d} \\
\left(\mathrm{~g} / \mathrm{cm}^{3}\right)\end{array}$ & $\begin{array}{c}n \\
(\%)\end{array}$ & $\begin{array}{c}a_{w} \\
(\%)\end{array}$ & $\begin{array}{c}V p \\
(\mathrm{~km} / \mathrm{s})\end{array}$ & $\begin{array}{c}\text { BA } \\
\left(\mathrm{cm}^{2} / 50 \mathrm{~cm}^{2}\right)\end{array}$ & $\begin{array}{c}\text { UCS } \\
(\mathrm{MPa})\end{array}$ & SHR \\
\hline Sille stone & 2.32 & 5.60 & 2.43 & 3.72 & 16.05 & 61.00 & 46 \\
\hline
\end{tabular}

Uniaxial compressive strength (UCS) mean value of Sille stone is $61.00 \mathrm{MPa}$ and Schmidt hammer rebound mean value is 46 . According to the classification made by NBG (1985), Sille stone is a "high porous rock". The UCS values of the stone were classified as "high strength" rock class based on ISRM (1979) classification.

\section{NON-DESTRUCTIVE TESTING RESULTS}

The main factor in the deterioration of building stones is the water content of the material. Water changes the physical behaviours and chemical properties of the material and causes irreversible damage (Hoła, Matkowski, and Hoła, 2017; Sandrolini and Franzoni, 2006). In conservation works, the determination of the presence and movement of water in building stones is crucial in terms of the determination of the origins of deterioration. For this purpose, relative humidity measurements were made from each building stone, and the measured values were presented in the maps (Figure 5).

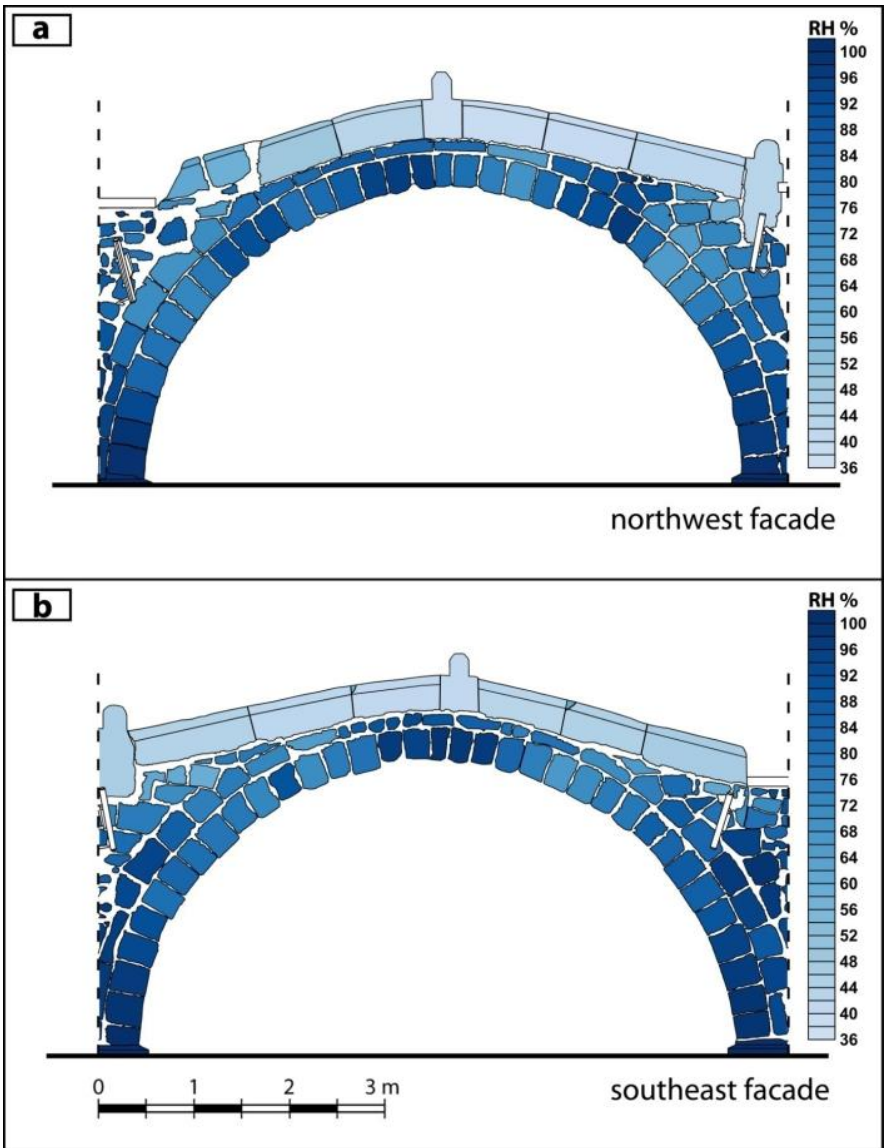

Figure 5. Relative humidity maps of stones in the Misırlıoglu Bridge, a) northwest facade, b) southeast facade. 
The relative humidity values of the building stones used on the outer surface of the bridge vary between $36 \%$ and $100 \%$. Upon examining the relative humidity maps, the presence of high humidity in the abutment and arch of the structure draws attention. The presence of humidity in the abutment is associated with the rise of the creek water under the capillary effect. The presence of humidity in the arch is due to the evaporation and then condensation of the creek water when it reaches the structure. Furthermore, different sizes of the stone facings forming the bridge floor are explained by the fact that the water leaking from the surface is drained from certain points of the arch (Figure 6).

Figure 6. Aerial photograph of the Mısırlığlu Bridge.

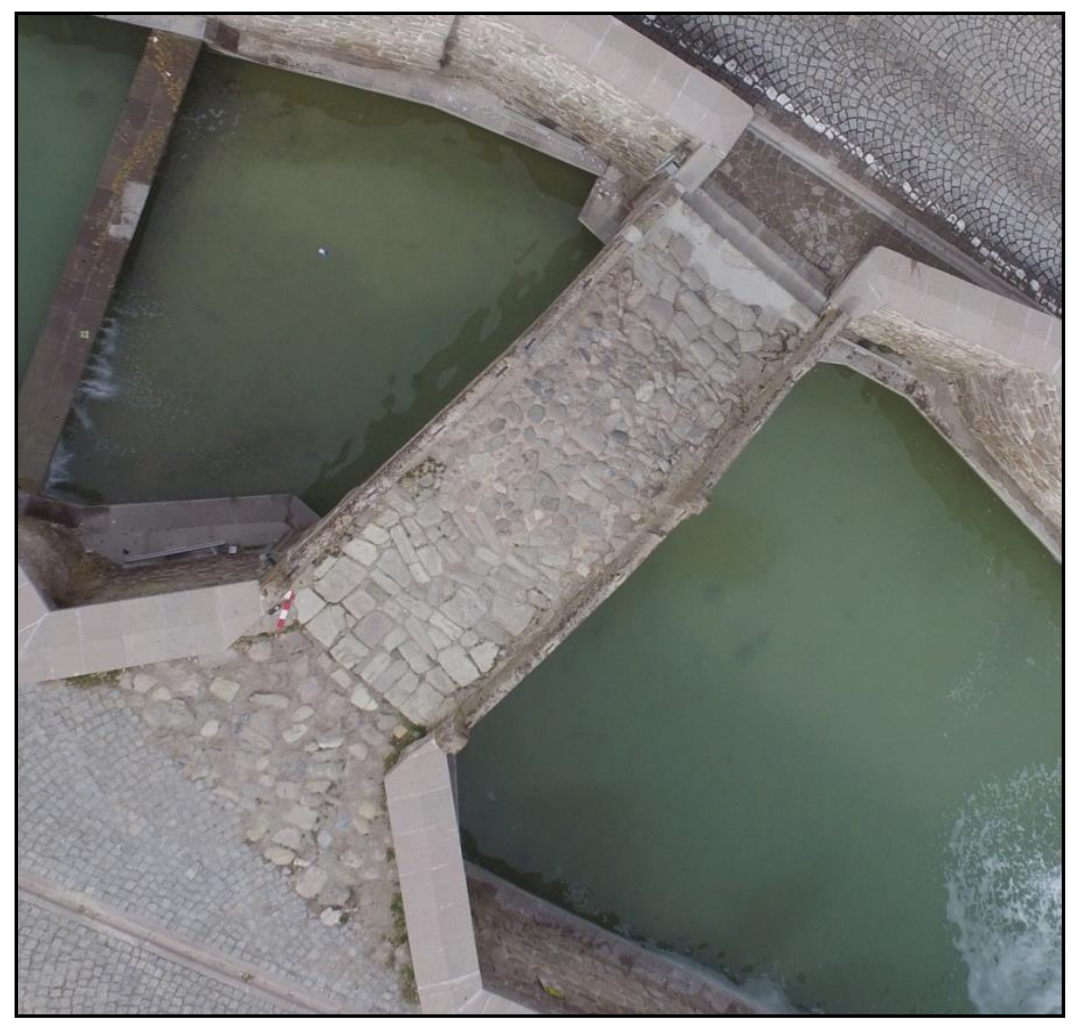

The surface hardness is one of the basic properties of the material. Decreases in the surface hardness value are directly associated with the deterioration status of the material. The Schmidt hammer rebound test is an NDT used to determine the surface hardness of stone materials (Hatır, Korkanç, and Başar, 2018; İnce, Bozdağ, Tosunlar, Hatır, and Korkanç, 2018; Korkanç, İnce, Hatır, and Tosunlar, 2018). There is a direct relationship between these test data and uniaxial compressive strengths of rocks (Aydin and Basu, 2005). In the study, the Schmidt hammer rebound test, which indirectly estimates the UCS, was applied to each building stone and the obtained values are presented in the maps (Figure 7). 
The Determination of Deteriorations on The Misırlığlu Bridge (Konya, Turkey) by Non-Destructive Techniques (NDT)

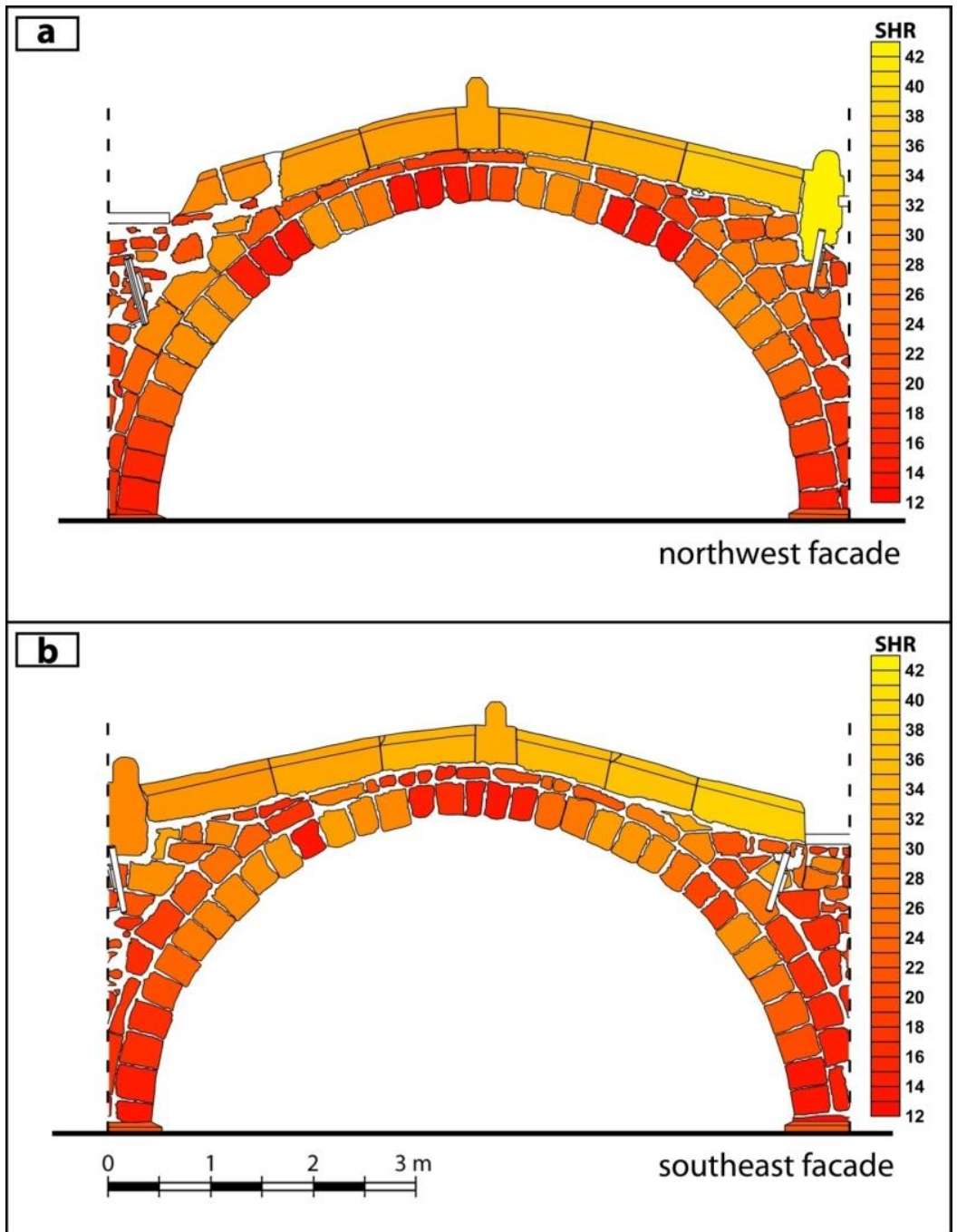

The Schmidt hammer rebound values in the stones used on the bridge vary between 12 and 42 . The UCS values of each building stone on the bridge were determined using the equation proposed by Fener, Kahraman, Bilgil, and Gunaydin (2005) (Equation 1). The statistical data on the estimated values in the northwest and southeast fronts of the bridge are presented in Table 3.

$U C S=4.24 * e^{0.059 * S H R}$

(Equation 1)

Table 3. Descriptive statistics of data used in the analysis.

\begin{tabular}{crrrr}
\hline \multirow{2}{*}{ Facades } & \multicolumn{4}{c}{ UCS-MPa } \\
\cline { 2 - 5 } & Minimum & maximum & mean & Standard deviation \\
\hline Northwest & 8.61 & 50.53 & 16.51 & 6.81 \\
Southeast & 8.61 & 39.91 & 16.33 & 6.55
\end{tabular}

The UCS values of the building stones of the bridge were determined to vary between Low-High strength according to ISRM (1979) (Table 4).
Figure 7. SHR distribution maps of the building stones in the Misırlıoglu Bridge, a) northwest facade, b) southeast facade. 
Mehmet Bahadır Tosunlar \& Mehmet Ergün Hatır \& İsmail İnce \& Ali Bozdağ \& Mustafa Korkanç

Table 4. Classification of the stone used in Mısırlığlu Bridge according to UCS values (Values in table are the number of stones measured, classification "low", "medium" and "high" according to UCS values was according to ISRM (1979)).

\begin{tabular}{cccc}
\hline \multirow{2}{*}{ Facades } & \multicolumn{3}{c}{ Estimation UCS - MPa } \\
\cline { 2 - 4 } & Low (5-15) & Medium (15-50) & High (50-120) \\
\hline Northwest & 55 & 50 & 1 \\
Southeast & 59 & 50 & - \\
\hline
\end{tabular}

Upon examining the prepared Schmidt hammer rebound maps, the hardness values were found to be low in the abutments and arch of the bridge. Moreover, there is also a significant relationship between the deterioration process and sizes of the building stones (Gökçe, İnce, Fener, Taşkıran, and Kayabali, 2016; Korkanç, 2018). As stone sizes decrease, the ratio of deterioration increases and the SHR value decreases. Deterioration types such as spalling, rounding, flaking, and efflorescence were observed in stones in which the SHR value decreased (Figure 8-9). Upon comparing, the data obtained from the Schmidt hammer rebound and relative humidity tests, the SHR values decrease in regions where water is active and the most intense deterioration is observed in these regions.

\section{DETERIORATIONS OBSERVED ON THE MISIRLIOĞLU BRIDGE}

As a result of the examinations performed on the Misırlığlu Bridge in Sille settlement, stone breakage, spalling, rounding, flaking, efflorescences, fissure (atmospheric); higher plant, lichen (biological), cement-based mortar, graffiti, and unoriginal stone (anthropogenic) deterioration types were determined, and then discoloration-deterioration maps were prepared (Figure 8, 9). Spalling (Figure 8a), flaking, and efflorescence types of deteriorations were determined in the abutments of the structure. In the arch part, rounding, flaking, geological weakness, and efflorescence deteriorations were determined (Figure 8b-e). The iron cramps in the railing systems on both sides of the bridge caused fissures due to thermal expansion and corrosion (Figure 8f). Intensive biological activities (lichen and algae) were observed in these regions (Figure 8g). The higher plant growth caused by mortar dissolution is partly noted in the structure (Figure 8h). Another problem on the bridge is man-made damage (stone breakage and graffiti) (Figure $8 \mathrm{i}$ and $\mathrm{j}$ ). Cement-based mortars applied unconsciously to the bridge (Figure 8k) caused efflorescence due to the salts they contain. Furthermore, unoriginal stones were used during the rehabilitation of the creek area (Figure 8l). 
The Determination of Deteriorations on The Misırlığlu Bridge (Konya, Turkey) by Non-Destructive Techniques (NDT)

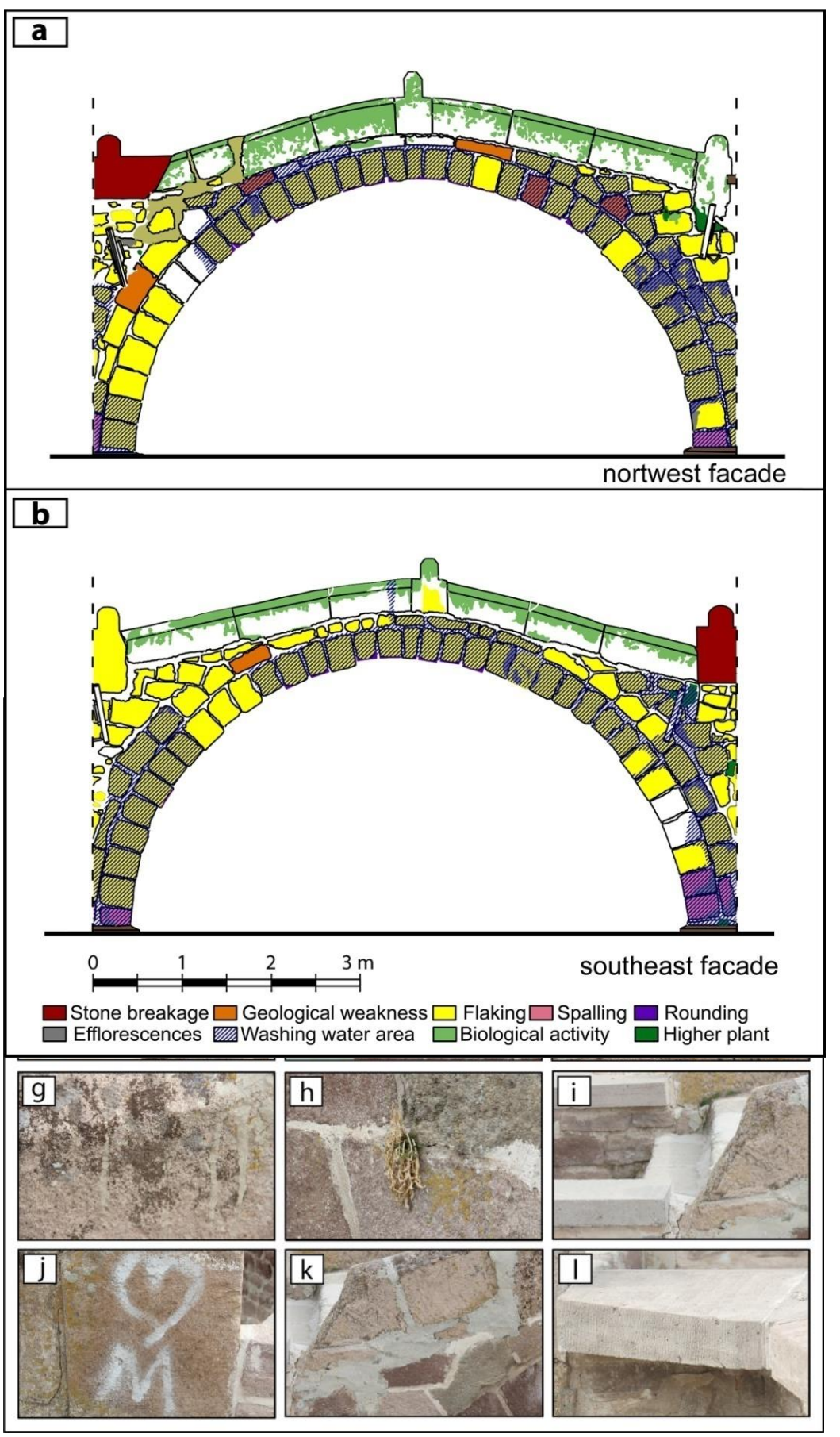

\section{CONCLUSION}

Sille stone is the most important building material that shapes the architectural texture of Konya and especially Sille settlement. Sille stone used in historic buildings in the region deteriorates due to various factors (environmental, climatic, biological, anthropogenic, etc.). The determination of the origins and degrees of influence of damage by NDT is extremely important for conservation works. In this study, deteriorations on the
Figure 8. Deterioration views in the Mısırlığlu Bridge; a) spalling, b) rounding, c) flaking, d) geological weakness and rounding, e) efflorescence, f) fissure, g) biological activity, h) higher plant, i) stone breakage, j) graffiti, k) cement based mortar, l) unoriginal stone.

Figure 9. Discoloration-deterioration maps of the Misırlıoğlu Bridge. 
Mehmet Bahadır Tosunlar \& Mehmet Ergün Hatır \& İsmail İnce \& Ali Bozdağ \& Mustafa Korkanç

Mısırlığlu Bridge located in Sille settlement were examined by NDT and the results obtained were presented below:

-The most effective deterioration detected in the structure is of atmospheric origin. In the deterioration process, the presence of humidity in the structure plays a crucial role. Upon examining the locations of the deteriorated stones and deterioration amounts with the SHR value map, it is observed that the highest deterioration is in the abutments and arch.

-The block sizes of the building stones used the bridge are highly effective in the deterioration process. Deterioration types and the status and the dimension of examined monument is important for selection of non-destructive techniques applied in the analysis of historic stone monuments.

-Based on the analysis it is detected that UCS values of the building stones used at the bridge decrease due to the atmospheric effects.

\section{REFERENCES}

ASTM. (1986). D2938. Standard test method for unconfined compressive strength of intact rock core specimens.

ASTM. (2014). D5873. Standard Test Method for Determination of Rock Hardness by rebound Hammer Method, Annual book of ASTM standards(American Society for Testing and Materials, West Conshohocken), 1-6.

Aydin, A., \& Basu, A. (2005). The Schmidt hammer in rock material characterization. Engineering Geology, 81(1), 1-14. doi:https://doi.org/10.1016/j.enggeo.2005.06.006

Beycan, A. D. 0. (2017). Evaluation of Sille Settlement in the Context of Ecological Tourizm. Iconarp International Journal of Architecture and Planning, 5(1), 151-171.

Delgado Rodrigues, J. (2015). Defining, mapping and assessing deterioration patterns in stone conservation projects. Journal of Cultural Heritage, 16(3), 267-275. doi:https://doi.org/10.1016/j.culher.2014.06.007

EN-14157. (2004). Natural Stone Determination of the Abrasion Resistance, Brussels.

Fener, M., \& Ince, I. (2015). Effects of the freeze-thaw (F-T) cycle on the andesitic rocks (Sille-Konya/Turkey) used in construction building. Journal of African Earth Sciences, 109, 96-106.

Fener, M., Kahraman, S., Bilgil, A., \& Gunaydin, O. (2005). A comparative evaluation of indirect methods to estimate the compressive strength of rocks. Rock Mechanics and Rock Engineering, 38(4), 329-343.

Gökçe, M. V., İnce, İ., Fener, M., Taşkıran, T., \& Kayabali, K. (2016). The effects of freeze-thaw (F-T) cycles on the Gödene travertine used in historical structures in Konya (Turkey). Cold Regions Science and Technology, 127, 65- 
The Determination of Deteriorations on The Mısırlığlu Bridge

(Konya, Turkey) by Non-Destructive Techniques (NDT)

75.doi:https://doi.org/10.1016/j.coldregions.2016.04.00 5

Hatır, M. E., Korkanç, M., \& Başar, M. E. (2018). Evaluating the deterioration effects of building stones using NDT: the Küçükköy Church, Cappadocia Region, central Turkey. Bulletin of Engineering Geology and the Environment. doi:10.1007/s10064-018-1339-x

Hoła, A., Matkowski, Z., \& Hoła, J. (2017). Analysis of the Moisture Content of Masonry Walls in Historical Buildings Using the Basement of a Medieval Town Hall as an Example. Procedia Engineering, 172, 363-368. doi:https://doi.org/10.1016/j.proeng.2017.02.041

İnce, İ., Bozdağ, A., Tosunlar, M. B., Hatır, M. E., \& Korkanç, M. (2018). Determination of deterioration of the main facade of the Ferit Paşa Cistern by non-destructive techniques (Konya, Turkey). Environmental Earth Sciences, 77(11), 420. doi:10.1007/s12665-018-7595-z

ISRM. (1979). Suggested methods for determining the uniaxial compressive strength and deformability of rock materials. Int J Rock Mech Min Sci Geomech Abst, 16, 135-140.

ISRM. (2007). The complete ISRM suggested methods for rock characterization, testing and monitoring: 1974-2006: International Soc. for Rock Mechanics, Commission on Testing Methods.

Karpuz, H. (2009). Türk kültür varlıkları envanteri: Konya 42, (Vol. 1): Türk Tarih Kurumu Yayınları.

Korkanç, M. (2013). Deterioration of different stones used in historical buildings within Nigde province, Cappadocia. Construction and Building Materials, 48, 789-803. doi:https://doi.org/10.1016/j.conbuildmat.2013.07.033

Korkanç, M. (2018). Characterization of building stones from the ancient Tyana aqueducts, Central Anatolia, Turkey: implications on the factors of deterioration processes. Bulletin of Engineering Geology and the Environment, 77(1), 237-252. doi:10.1007/s10064-016-0930-2

Korkanç, M., İnce, İ., Hatır, M. E., \& Tosunlar, M. B. (2018). Historical Granaries at Taşkale (Turkey) Under Risk: A Geotechnical Analysis. Mediterranean Archaeology \& Archaeometry, 18(1).

Le Bas, M. J., Le Maitre, R. W., Streckeisen, A., \& Zanettin, B. (1986). A chemical classification of volcanic rocks based on the total alkali-silica diagram. Journal of petrology, 27(3), 745-750.

NBG. (1985). Engineering Geology and Rock Engineering. Norwegian Group of Rock Mechanics, Norway.

Ozdemir, A. (2002). Capillary water absorption potential of some building materials. Geological Engineering, 26(1), 19-32.

Sandrolini, F., \& Franzoni, E. (2006). An operative protocol for reliable measurements of moisture in porous materials of ancient buildings. Building and Environment, 41(10), 1372-1380. doi:https://doi.org/10.1016/j.buildenv.2005.05.023

Zedef, V., Kocak, K., Doyen, A., Ozsen, H., \& Kekec, B. (2007). Effect of salt crystallization on stones of historical buildings and 
Mehmet Bahadır Tosunlar \& Mehmet Ergün Hatır \& İsmail İnce \& Ali Bozdağ \& Mustafa Korkanç

monuments, Konya, Central Turkey. Building and Environment, 42(3), 1453-1457.

doi:https://doi.org/10.1016/j.buildenv.2005.12.010

\section{Resume}

M. Bahadır Tosunlar, graduated from Eskişehir Osmangazi University, Department of Architecture in 2006. He worked for various positions in field of architecture. Afterwards, He received master's degree in 2015 from Selçuk University Institute of Science by completing Architectural Restoration Master Programme. Currently, Tosunlar is holding the position of research assistant in Konya Technical University, Department of Architecture and continues doctorate in Konya Technical University, Architectural Restoration Phd Programme.

Mehmet Ergün Hatır, graduated from Selçuk University, Department of Architecture in 2011. He received master's degree in 2014 from Gazi University Institute of Science by completing Architectural Restoration Master Programme. Currently, he continues doctorate in Konya Technical University Architectural Restoration Phd Programme. He research interests include building stones, stone deteriorations and cultural heritage.

Dr. İsmail Ince, research assistant, graduated from the Department of Geological Engineering at Selçuk University (Turkey) with a B.S. in 2000. He received his M.S. (2004) and Ph.D. (2013) degrees from the same department. His research interest are rock mechanics and building materials.

Dr. Ali Bozdağ graduated from Department of Geological Engineering at Selçuk University and received his Ph.D. at the same university. His research interest include engineering geology, rock mechanics and natural building materials.

Mustafa Korkanç was born in Niğde, on August 15, 1971. He received the Diploma in Geological Engineering from Istanbul University and the Master's degree from Niğde University. He Ph.D. degree is from Istanbul University. He is currently working in Niğde Ömer Halisdemir University as a Assoc. professor in Department of Applied Geology. He research interests include natural stones, cultural heritage, stone deteriorations, raw materials and aggregates. 